\title{
Quantitative Structure-Activity Relationships (QSAR) of 4-Amino-2,6-diarylpyrimidine- 5-carbonitriles with Anti-inflammatory Activity
}

\author{
João Bosco P. da Silva, ${ }^{a}$ Mozart N. Ramos, ${ }^{* a}$ Benício de Barros Neto, ${ }^{a}$ Sebastião José de Melo, ${ }^{*}, b$ \\ Emerson Peter da Silva Falcão ${ }^{c}$ and Maria Teresa J. de Almeida Catanho ${ }^{d}$
}

${ }^{a}$ Departamento de Química Fundamental, Universidade Federal de Pernambuco, 50740-540 Recife-PE, Brazil

${ }^{b}$ Departamento de Antibióticos, Universidade Federal de Pernambuco, 50740-521 Recife-PE, Brazil

${ }^{c}$ Centro Acadêmico de Vitória de Santo Antão, Universidade Federal de Pernambuco, 55608-680, Recife-PE, Brazil

${ }^{d}$ Departamento de Biofísica e Radiobiologia, Universidade Federal de Pernambuco, 50670-901 Recife-PE, Brazil

\begin{abstract}
As atividades antiinflamatórias de oito compostos 4-amino-2,6-diarilpirimidina-5-carbonitrilas foram sujeitas a uma análise QSAR baseada nos resultados de cálculos de estrutura eletrônica B3LYP/6-31G(d,p) e AM1. Análise de Componentes Principais e regressões baseados nesses dados indicam que compostos potencialmente mais ativos teriam menores valores de momentos de dipolo e de coeficientes de partição e também seriam afetados pelos valores de cargas dos átomos de carbono através dos quais os dois anéis aromáticos estão ligados ao anel pirimidínico. Duas novas moléculas foram previstas serem, ao menos, tão ativas como aquelas com as maiores atividades usadas no estágio de construção do modelo. Uma delas, tendo o grupo metoxila conectado a um dos anéis aromáticos, foi prevista ter um valor de atividade antiinflamatória de 52,3\%. Essa molécula foi sintetizada e sua atividade experimental foi determinada em 52,8\%, em concordância com a previsão teórica AM1. Esse valor é 5\% maior que o maior valor usado para a modelagem.
\end{abstract}

The experimental anti-inflammatory activities of eight 4-amino-2,6-diarylpyrimidine-5carbonitriles were subjected to a QSAR analysis based on results from B3LYP/6-31G(d,p) and AM1 electronic structure calculations. Principal component analyses and regressions based on these data indicate that potentially more active compounds should have low dipole moment and partition coefficient values and also be affected by the values of the charges of the carbon atoms through which the two aromatic rings are bonded to the pyrimidinic ring. Two new molecules were predicted to be at least as active as those with the highest activities used in the model building stage. One of them, having a methoxy group attached to one of the aromatic rings, was predicted to have an anti-inflammatory activity value of $52.3 \%$. This molecule was synthesized and its experimental activity was found to be $52.8 \%$, in agreement with the AM1 theoretical prediction. This value is $5 \%$ higher than the largest value used for modeling.

Keywords: pyrimidine derivatives, anti-inflammatory activity, molecular modeling, QSAR

\section{Introduction}

It is well known ${ }^{1-5}$ that heterocyclic compounds containing pyrimidinic rings can present antifungal, ${ }^{1}$ antitumoral $^{2}$ and anti-inflammatory action, ${ }^{3}$ among other pharmacological activities. The pharmacological action is mainly observed when the amino group is bonded to

*e-mail: mramos@ufpe.br; melosebastiao@yahoo.com.br the pyrimidinic ring at the 2- and/or 4- positions. ${ }^{4}$ Kansy et $a l .{ }^{5}$ have synthesized new derivatives of 2,4-diamino5-benzylpyrimidines, to evaluate their inhibitory activity against dihydrofolate reductase (DHFR), and observed that the inhibitory action against this enzyme is much larger than that of other conventional drugs, like sulfadiazine. More recently, Gangjee et al. ${ }^{6}$ have also observed that two series of nonclassical antifolates (2,4-diamino-5-deaza compounds and 5,10-dideaza compounds) are potent inhibitors of DHFR from Pneumocystis carinii $(p c)$ and 
Toxoplasma gondii $(\mathrm{tg})$, which cause fatal opportunistic infections in AIDS patients.

These results have encouraged new investigations involving pyrimidinic derivatives with an amino group at position 4. In the past few years, Melo and collaborators have attempted to synthesize new pyrimidinic compounds and evaluate their anti-inflammatory activities. ${ }^{7}$ Recently, they have successfully synthesized a set of new 4-amino2,6-diarylpyrimidine-5-carbonitriles, ${ }^{8}$ whose structures are shown in Figure 1.

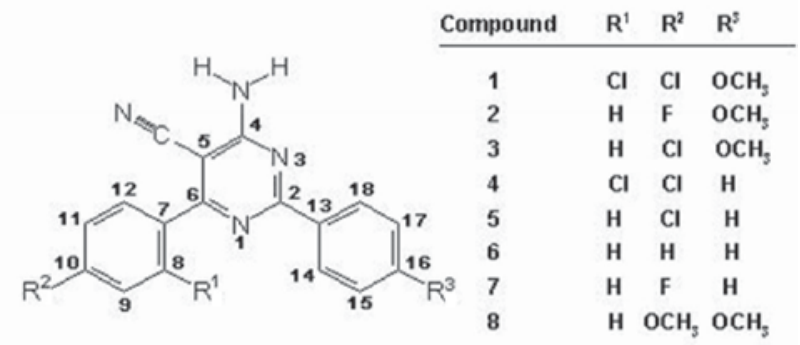

Figure 1. Series of newly synthesized 4-amino-2,6-diarylpyrimidine-5carbonitriles.

These derivatives have shown a significant antiinflammatory activity (AA), as evaluated by their action on carrageenan-induced mouse paw edema. ${ }^{9,10}$ They have also presented low toxicity after intraperitoneal administration to groups of ten Swiss adult albino mice (20-22 g). ${ }^{9,11}$ It has been observed that their activities are drastically changed by modifications in the substituents bonded to positions 2 and 6 of the pyrimidinic ring. For instance, when the $\mathrm{R}^{2}$ group is a chlorine atom, as in compound $\mathbf{5}$, the drug's antiinflammatory activity is $20.7 \%$. If chlorine is substituted by fluorine (compound 7 ), the anti-inflammatory action increases to $47.3 \%$, which is larger than the $36.5 \%$ value observed when the traditional acetylsalicylic acid (ASA) is administered at a dose of $250 \mathrm{mg} / \mathrm{kg}$. On the other hand, when a hydrogen atom at $\mathrm{R}^{1}$ is substituted by chlorine (compounds $\mathbf{3}$ and $\mathbf{1}$ ), the anti-inflammatory activity is reduced from $17.1 \%$ to $4.9 \%$.

In an attempt to find out what structural modifications contribute to these pharmacological changes, we examined this series of 4-amino-2,6-diarylpyrimidine5 -carbonitriles, ${ }^{10}$ searching for a relation between the experimentally determined anti-inflammatory activities and electronic parameters obtained from molecular orbital calculations. To validate the mathematical relationships obtained, we synthesized the most active compound predicted by the analysis and measured its anti-inflammatory activity.

\section{Experimental}

\author{
Synthesis
}

The starting 4-substituted benzaldehyde $\mathbf{1}$ was allowed to react with malononitrile $\mathbf{2}$, to produce the convenient unsaturated bisnitrile 3. Condensation of that compound with arilamidine in the presence of piperidine yielded 4-amino-6(phenyl)-2-(p-anizyl)-5-cyano-pyrimidine (9). The synthetic pathway leading to compound $\mathbf{9}$ is shown in Scheme 1.
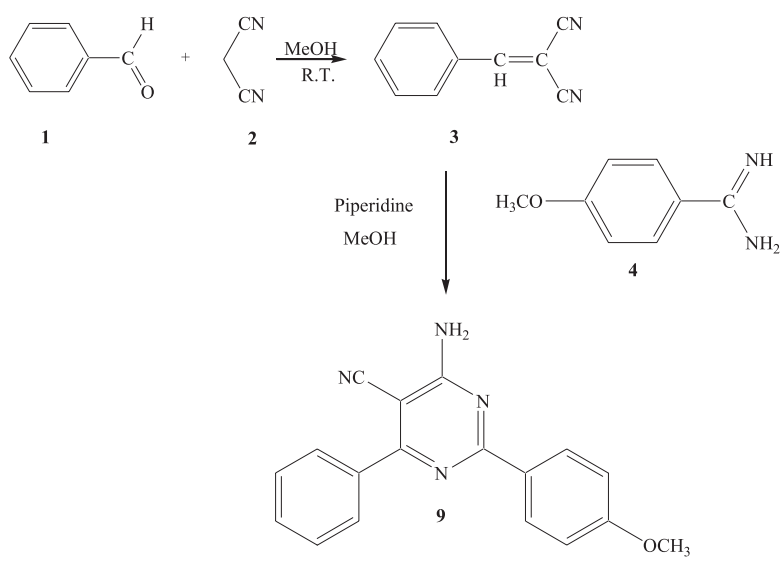

Scheme 1.

Preparation of 4-amino-2-(phenyl) -6-(p-anizyl)-5-cyanopyrimidine (9)

Bisnitrile $(5.36 \mathrm{mmol})$ and arylamidine $(5.36 \mathrm{mmol})$ were dissolved in methanol $(20 \mathrm{~mL})$ and refluxed for 7 h. The contents were cooled to room temperature and the solvent evaporated under reduced pressure to give a solid mass, which was cromatographed over silica gel. The desired compound was eluted using a mixture of $n$-hexane/ ethyl acetate (4:1). The fractions containing compound 9 were combined, the solvent evaporated, and the product was crystallized in methanol.

\section{Chemical analysis}

The sample IR spectrum was recorded with a Bruker spectrometer model IFS 66 (Fourier Transform) utilizing $\mathrm{KBr}$ pellets. The EI mass spectrum was obtained with a Delsi-Nermag mass spectrometer, coupled to a GC (HP 5890) at an ionization potential of $70 \mathrm{eV}$. The ${ }^{1} \mathrm{H}-\mathrm{NMR}$ spectrum was recorded with a $300 \mathrm{MHz}$ Varian spectrometer model UNITY plus. The Melting point was obtained with an Electrothermal digital melting point apparatus (model 9100) and is uncorrected. Thin-layer chromatography was carried out on plates coated with silica gel containing the fluorescent indicator F254 and the spots were detected 
under ultraviolet light. The solvent system was ethyl acetate/hexane (4:1).

\section{4-Amino-2-(phenyl) -6-(p-anizyl)-5-cyano-pyrimidine (9)}

This compound was obtained as white crystals with a yield of 54.6\%; $\mathrm{mp} 214-215^{\circ} \mathrm{C} ; \mathrm{R}_{\mathrm{f}}=0.39$ ( $n$-hexane/ethyl acetate, 8:2); (KBr, $\left.v_{\max } / \mathrm{cm}^{-1}\right): 3475\left(\mathrm{NH}_{2}\right.$ asymm $), 3343$ $\left(\mathrm{NH}_{2 \text { symm }}\right), 2217(\mathrm{CN}), 1638(\mathrm{C}=\mathrm{N})$; ${ }^{1} \mathrm{H}-\mathrm{NMR}$ : (DMSO-d ${ }_{6}$, $300 \mathrm{MHz}), \delta 8.38\left(\mathrm{~m}, 2 \mathrm{H}, J=9.0 \mathrm{~Hz}, \mathrm{H}_{2}{ }^{\prime}, \mathrm{H}_{6}{ }^{\prime}\right), 7.12$ (d, $2 \mathrm{H}, J 9.0 \mathrm{~Hz}, \mathrm{H}_{3}$ ", $\mathrm{H}_{5}$ ") 7.72 (sL, 2H, NH${ }_{2}$ ), 8.0 (d, 2H, $J 8.7 \mathrm{~Hz}, \mathrm{H}_{2}{ }^{\prime}, \mathrm{H}_{6}{ }^{\prime}$ ), 7.52 (m, 3H, J $8.1 \mathrm{~Hz}, \mathrm{H}_{3}{ }, \mathrm{H}_{5}{ }^{\prime}, \mathrm{H}_{4}{ }^{\prime}$ ), 3.84 (s, $\left.3 \mathrm{H}, \mathrm{CH}_{3} \mathrm{O}\right), \mathrm{MS}: \mathrm{m} / z$ (rel. int.) $317\left(\mathrm{M}^{+}, 100\right)$, 318 (49.66). Anal. Calculated for $\mathrm{C}_{18} \mathrm{H}_{14} \mathrm{~N}_{4} \mathrm{O} .1 / 4 \mathrm{H}_{2} \mathrm{O}$ : C, $61,44 \%$; H, 3.86\%; N, 19.90\%. Found: C, 61.40\%; H, $3.75 \% ; \mathrm{N}, 19.96 \%$.

\section{Methods}

\section{Software}

To obtain the electronic properties of the compounds considered in this work, quantum-chemical calculations were performed at two levels, with the GAUSSIAN 94 program: ${ }^{12}$ (i) semi-empirical $\mathrm{AM} 1^{13}$ and (ii) Density Functional Theory (DFT) ${ }^{14}$ using the hybrid functional B3LYP ${ }^{15}$ with a 6-31G(d,p) basis set. ${ }^{16}$ All statistical calculations were carried out with the Statistica 6.1 software. ${ }^{17}$ Octanol/water partition coefficient values were estimated with the Kowwin v1.67 program. $^{18}$ All calculations were performed on a PC (Pentium III, 800 MHz, 512MB RAM, 30GB HD).

\section{Pharmacology}

The anti-inflammatory assays were preceded by acute toxicity tests in mice. The pyrimidine derivatives were individually dissolved in a prepared $2.5 \%$ Tween 80 solution diluted in $0.9 \%$ saline water. Intraperitoneal administration of this suspension $(0.5 \mathrm{~mL})$ to the animals at doses of 125 , 250,500 and $1000 \mathrm{mg} \mathrm{kg}^{-1}$ of body weight did not show any toxic effects after 4-72 hours waiting periods.

Anti-inflammatory tests were performed for the compounds shown in Figure 1, using $250 \mathrm{mg} \mathrm{kg}^{-1}$ doses in groups of 10 Swiss albino mice. All the compounds exhibited anti-inflammatory activity, ranging from $4.9 \%$ to $47.8 \%$.

\section{Calculations}

The molecular geometry of each compound was fully optimized at both calculation levels and no imaginary frequency was observed. From these calculations we determined the frontier orbital energy values, Mulliken net charges, molecular electric dipole moments and the molar volume $\left(\mathrm{V}_{\mathrm{m}}\right)$ for all studied molecules. Initially, the molecular geometry of the parent compound $(\mathbf{6})$ with $\mathrm{R}^{1}=\mathrm{R}^{2}=\mathrm{R}^{3}=\mathrm{H}$ was fully optimized. In this procedure, the $\mathrm{N}_{1} \mathrm{C}_{2} \mathrm{C}_{13} \mathrm{C}_{14}$ and $\mathrm{C}_{12} \mathrm{C}_{7} \mathrm{C}_{6} \mathrm{C}_{5}$ dihedral angles between the aromatic rings and the pyrimidinic ring were allowed to vary. After optimization, however, the B3LYP/6-31G(d,p) calculations revealed that the $\mathrm{N}_{1} \mathrm{C}_{2} \mathrm{C}_{13} \mathrm{C}_{14}$ angle is close to zero, i.e., the aromatic ring containing the $\mathrm{R}^{3}$ group is practically on the same plane of the pyrimidinic ring, in contrast to what happens with the other aromatic ring. The optimized dihedral angles for the eight structures are given in Table 1.

Table 1. B3LYP/6-31G(d,p) and AM1 values of the $\mathrm{N}_{1} \mathrm{C}_{2} \mathrm{C}_{13} \mathrm{C}_{14}$ and $\mathrm{C}_{12} \mathrm{C}_{7} \mathrm{C}_{6} \mathrm{C}_{5}$ dihedral angles for the fully optimized minimum energy structures of the 4-amino-2,6-diarylpyrimidine-5-carbonitriles shown in Figure 1

\begin{tabular}{ccccc}
\hline \multirow{2}{*}{ Compound } & \multicolumn{4}{c}{ Dihedral Angle $\left(^{\circ}\right)$} \\
& \multicolumn{2}{c}{$\mathrm{N}_{1} \mathrm{C}_{2} \mathrm{C}_{13} \mathrm{C}_{14}$} & \multicolumn{2}{c}{$\mathrm{C}_{12} \mathrm{C}_{7} \mathrm{C}_{6} \mathrm{C}_{5}$} \\
& $\mathrm{~B} 3 \mathrm{LYP}$ & $\mathrm{AM} 1$ & $\mathrm{~B} 3 \mathrm{LYP}$ & $\mathrm{AM} 1$ \\
\hline $\mathbf{1}$ & -1.2 & 33.6 & 57.4 & 78.7 \\
$\mathbf{2}$ & 2.8 & 35.1 & 32.5 & 50.5 \\
$\mathbf{3}$ & 2.6 & 34.9 & 32.5 & 51.0 \\
$\mathbf{4}$ & -1.5 & 38.1 & 57.1 & 79.8 \\
$\mathbf{5}$ & 2.4 & 38.7 & 32.2 & 50.8 \\
$\mathbf{6}$ & 2.9 & 38.9 & 33.6 & 50.9 \\
$\mathbf{7}$ & 3.6 & 38.8 & 31.9 & 50.4 \\
$\mathbf{8}$ & 2.5 & 35.0 & 30.3 & 49.5 \\
\hline
\end{tabular}

The B3LYP/6-31G(d,p) value of the dihedral angle $\mathrm{C}_{12} \mathrm{C}_{7} \mathrm{C}_{6} \mathrm{C}_{5}$ is close to $30^{\circ}$ for most compounds, but increases to about $57^{\circ}$ in compounds $\mathbf{1}$ and $\mathbf{4}$, for which $\mathrm{R}^{1}=\mathrm{Cl}$. The same pattern is observed in the AM1 results, except that the values are now all higher than the corresponding B3LYP angles. However, the AM1 calculations show that the most stable conformation corresponds to a minimum energy structure in which both aromatic rings are non-planar to the pyrimidinic ring. For the six compounds without a chlorine atom at $\mathrm{R}^{1}$, the $\mathrm{N}_{1} \mathrm{C}_{2} \mathrm{C}_{13} \mathrm{C}_{14}$ and $\mathrm{C}_{12} \mathrm{C}_{7} \mathrm{C}_{6} \mathrm{C}_{5} \mathrm{AM} 1$ dihedral angle variation is slight: $34-38^{\circ}$ and $49-51^{\circ}$, respectively. Introduction of a chlorine atom at $\mathrm{R}^{1}$ (compounds $\mathbf{1}$ and 4) increases the $\mathrm{C}_{12} \mathrm{C}_{7} \mathrm{C}_{6} \mathrm{C}_{5}$ dihedral angle to about $79^{\circ}$.

A set of basic descriptors was used in regressions to predict the anti-inflammatory activity of the compounds. Some of the electronic descriptors are highly correlated among themselves, which could cause statistical instability in the ordinary multiple regression equations due to multicollinearity. Therefore, we first performed a principal 
component analysis (PCA) on them, and regressed the dependent variable, AA, on the scores obtained from the PCA, instead of on the descriptors themselves.

In a principal component analysis, the original data matrix is projected onto a subspace defined by linear combinations of the original variables with maximum variance - that is, maximum information - and orthogonal to each other. ${ }^{19}$ The first principal component (PC1) is the axis describing the maximum possible variance in the original multidimensional space; the second component is orthogonal to $\mathrm{PC} 1$ and describes the maximum variance not already described by PC1, and so on. The orthogonality between different PC axes eliminates the regression multicollinearity problem.

Each principal component is characterized by three mathematical entities: (i) the percent amount of explained variance; (ii) a loadings vector, whose elements are the cosines of the angles the PC axis forms with the original variable axes; (iii) a scores vector, containing the coordinates locating the individual compounds in the PC axis. A regression on the scores of a PCA is called a principal component regression. ${ }^{20}$

\section{Results and Discussion}

The B3LYP and AM1 descriptors having absolute correlation coefficients with the AA values larger than $c a$. 0.4, were selected for the regression step. These, together with $\log \mathrm{P}$, which has a correlation coefficient of -0.70 with the anti-inflammatory activity, form the set of descriptors for each pyrimidinic derivative. Their values for the eight compounds are given in Table 2.

A principal component analysis based on the correlation matrix of the five descriptors was carried out, using the DFT calculated values. The loadings plot of first two components, which together account for $86 \%$ of the total information, is shown in Figure 2(a). The antiinflammatory activity is also projected on this plot, but was not used in the PCA calculations. It almost exactly coincides with the positive side of the PC1 axis. On the same side, and close to $\mathrm{AA}$, is $\mathrm{qC}_{13}$, whereas the other four descriptors have negative loadings on PC1. This means that high anti-inflammatory values are expected to be associated with high $\mathrm{qC}_{13}$ values and with low values of the other four descriptors. The corresponding scores plot is shown in Figure 2(b). Overall, the more active compounds have more positive scores on PC1. The least active compound $\mathbf{1}$ has the most negative PC1 score. The score on the first component, therefore, can be interpreted as a composite theoretical measure of anti-inflammatory activity.
Table 2. Anti-inflammatory activities (AA) and B3LYP/6-31G(d,p) and AM1 electronic parameters for the 4-amino-2,6-diarylprymidine-5carbonitriles in Figure 1. AM1 values are given in parentheses

\begin{tabular}{|c|c|c|c|c|c|c|}
\hline $\begin{array}{l}\text { Com- } \\
\text { pound }\end{array}$ & $\begin{array}{l}\text { AA } \\
(\%)\end{array}$ & $\mu(\mathrm{D})$ & $\mathrm{qC}_{7}(\mathrm{e})$ & $\mathrm{qC}_{13}(\mathrm{e})$ & $\mathrm{qC}_{16}(\mathrm{e})$ & $\log P$ \\
\hline 1 & 4.9 & $\begin{array}{c}4.08 \\
(2.61)\end{array}$ & $\begin{array}{c}0.086 \\
(-0.048)\end{array}$ & $\begin{array}{c}0.036 \\
(-0.084)\end{array}$ & $\begin{array}{c}0.364 \\
(0.103)\end{array}$ & 4.02 \\
\hline 2 & 10.9 & $\begin{array}{c}4.04 \\
(4.33)\end{array}$ & $\begin{array}{c}0.063 \\
(-0.077)\end{array}$ & $\begin{array}{c}0.039 \\
(-0.084)\end{array}$ & $\begin{array}{c}0.363 \\
(0.102)\end{array}$ & 2.93 \\
\hline 3 & 17.1 & $\begin{array}{c}4.50 \\
(2.68)\end{array}$ & $\begin{array}{c}0.065 \\
(-0.061)\end{array}$ & $\begin{array}{c}0.038 \\
(-0.084)\end{array}$ & $\begin{array}{c}0.363 \\
(0.103)\end{array}$ & 3.37 \\
\hline 4 & 20.3 & $\begin{array}{c}3.59 \\
(2.72)\end{array}$ & $\begin{array}{c}0.085 \\
(-0.048)\end{array}$ & $\begin{array}{c}0.039 \\
(-0.044)\end{array}$ & $\begin{array}{c}-0.073 \\
(-0.171)\end{array}$ & 3.94 \\
\hline 5 & 20.7 & $\begin{array}{c}3.81 \\
(2.92)\end{array}$ & $\begin{array}{c}0.065 \\
(-0.062)\end{array}$ & $\begin{array}{c}0.042 \\
(-0.045)\end{array}$ & $\begin{array}{c}-0.073 \\
(-0.172)\end{array}$ & 3.29 \\
\hline 6 & 38.7 & $\begin{array}{c}2.09 \\
(1.55)\end{array}$ & $\begin{array}{c}0.066 \\
(-0.064)\end{array}$ & $\begin{array}{c}0.042 \\
(-0.043)\end{array}$ & $\begin{array}{c}-0.074 \\
(-0.173)\end{array}$ & 2.65 \\
\hline 7 & 47.3 & $\begin{array}{c}3.18 \\
(3.19)\end{array}$ & $\begin{array}{c}0.063 \\
(-0.078)\end{array}$ & $\begin{array}{c}0.042 \\
(-0.044)\end{array}$ & $\begin{array}{c}-0.074 \\
(-0.172)\end{array}$ & 2.85 \\
\hline 8 & 47.8 & $\begin{array}{c}2.34 \\
(1.77) \\
\end{array}$ & $\begin{array}{c}0.063 \\
(-0.101) \\
\end{array}$ & $\begin{array}{c}0.039 \\
(-0.082) \\
\end{array}$ & $\begin{array}{c}0.362 \\
(0.101) \\
\end{array}$ & 2.81 \\
\hline
\end{tabular}

A regression of the AA values on the $\mathrm{PC} 1$ scores yields the equation

$\mathrm{AA}=25.96( \pm 3.80)+7.61( \pm 2.35) \mathrm{t}_{1}$,

With $\mathrm{R}^{2}=0.64, \mathrm{~F}_{1,6}=10.46$ and $\mathrm{p}=0.018$, where $\mathrm{t}_{1}$ stands for the score on the PC1 axis. The values in parentheses are the standard error estimates of the regression coefficients. Though the $\mathrm{R}^{2}$ value is not very impressive, both coefficients are statistically significant at the $95 \%$ confidence level.

When the same analysis is performed with AM1 descriptors, the PCA results are slightly different. The loadings plot is shown in Figure 3. The information reproduced by the first two $\mathrm{PCs}$ is $82 \%$, almost the same as when the DFT descriptors were used, but high antiinflammatory activities now appear to be associated with negative scores on PC2. A regression of the AA values on these scores results in the equation

$\mathrm{AA}=25.96( \pm 3.54)-9.75( \pm 2.71) \mathrm{t}_{2}$

With $\mathrm{R}^{2}=0.68, \mathrm{~F}_{1,6}=12.97$ and $\mathrm{p}=0.011$. Both coefficients are again significant, and the negative sign for the $t_{2}$ coefficient indicates that highly positive scores on the second principal component are expected to be associated with poor anti-inflammatory activities, as already suggested by the loadings plot. Moreover, the pattern of the variable loadings along PC2 is strikingly similar to the one observed along PC1 with the DFT values.

Despite the difference in the PCA results, both regressions yield very similar predictions for the AA values, 
a)

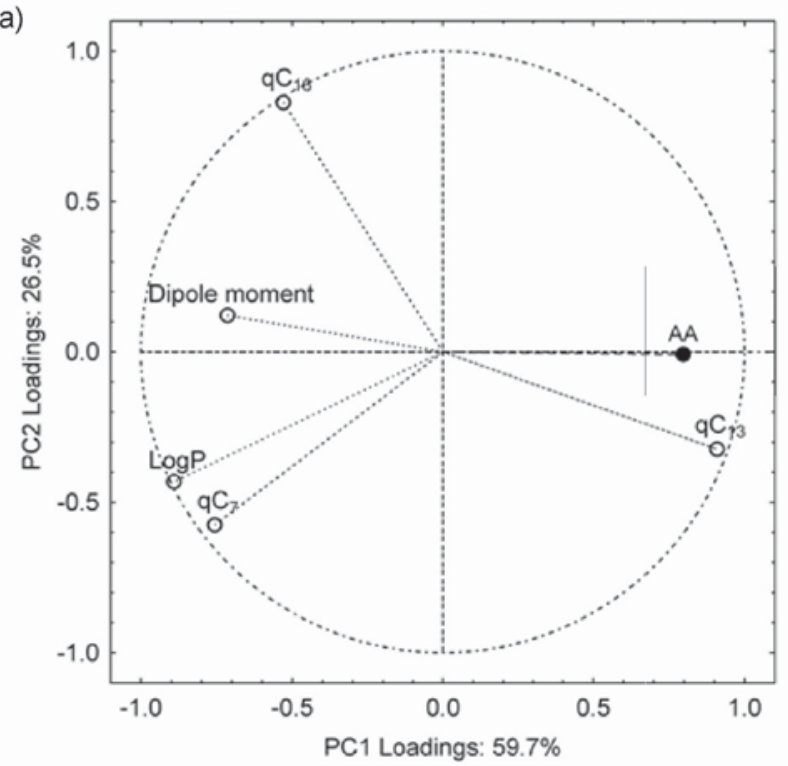

b)

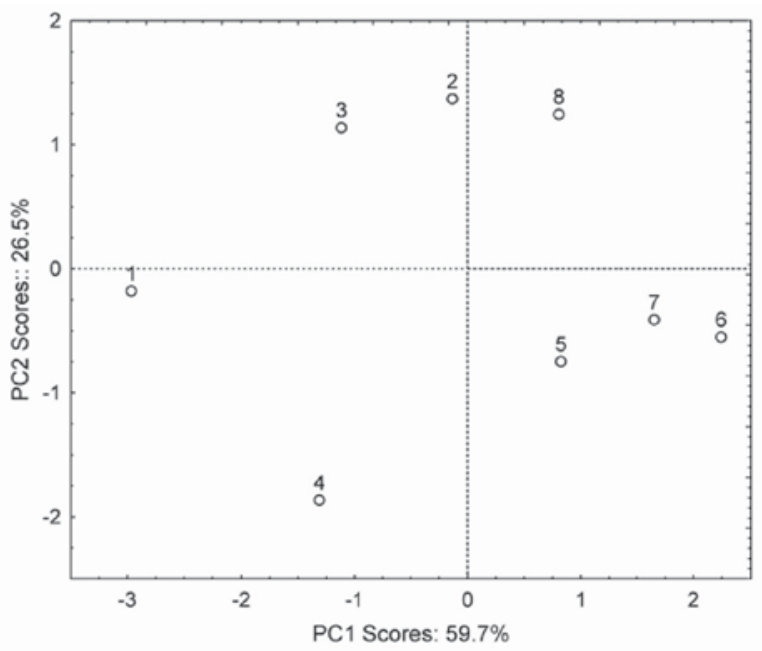

Figure 2. Results of the principal component analysis performed on the DFT results plus $\log$ P. (a) Loadings plot. (b) Scores plot. The percent information reproduced by each component is given in the respective axis title.

as can be visualized in Figure 4, where the predicted values are plotted against the experimental ones. Where only one number appears, as for compounds $\mathbf{1}$ and $\mathbf{7}$, for example, the predictions are so close that their points in the plot overlap. The corresponding numerical values are given in Table 3 .

An AM1 conformational analysis on the parent compound $6\left(\mathrm{R}^{1}=\mathrm{R}^{2}=\mathrm{R}^{3}=\mathrm{H}\right)$ revealed the existence of other stable conformations corresponding to minimum energy values, caused by rotation of the $\mathrm{C}_{6}-\mathrm{C}_{7}$ and $\mathrm{C}_{2}-\mathrm{C}_{13}$ bonds. This led us to investigate the possible influence of the conformational effect on the QSAR regression model. The most stable conformation using the B3LYP calculations indicates that the $\mathrm{N}_{1} \mathrm{C}_{2} \mathrm{C}_{13} \mathrm{C}_{14}$ dihedral angle is close to zero, that is, the aromatic ring containing the $\mathrm{R}^{3}$ group and the pyrimidinic ring are practically on the same

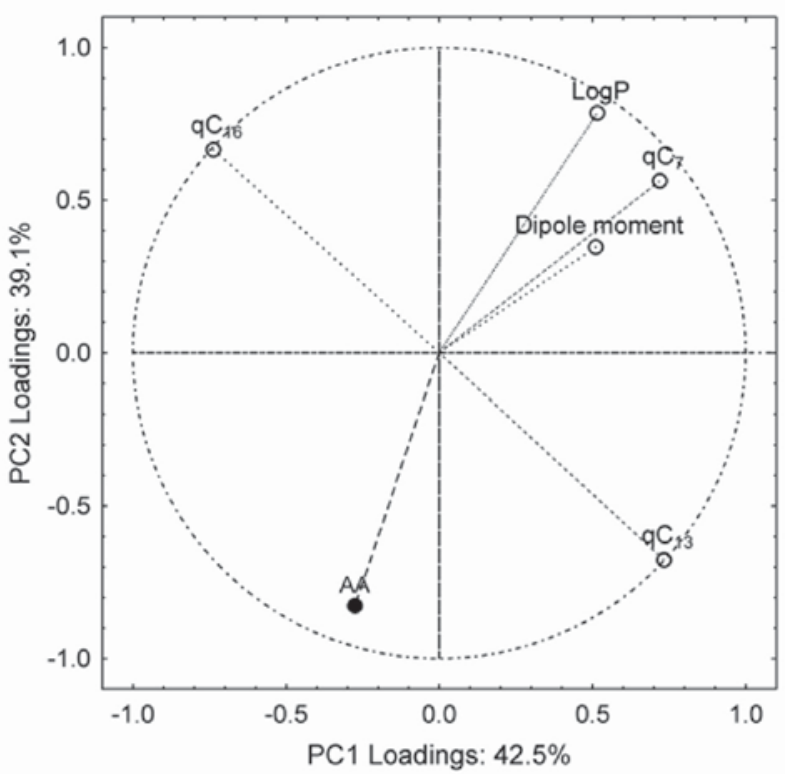

Figure 3. Loadings plot for the PCA carried out on the AM1 results plus $\log \mathrm{P}$.

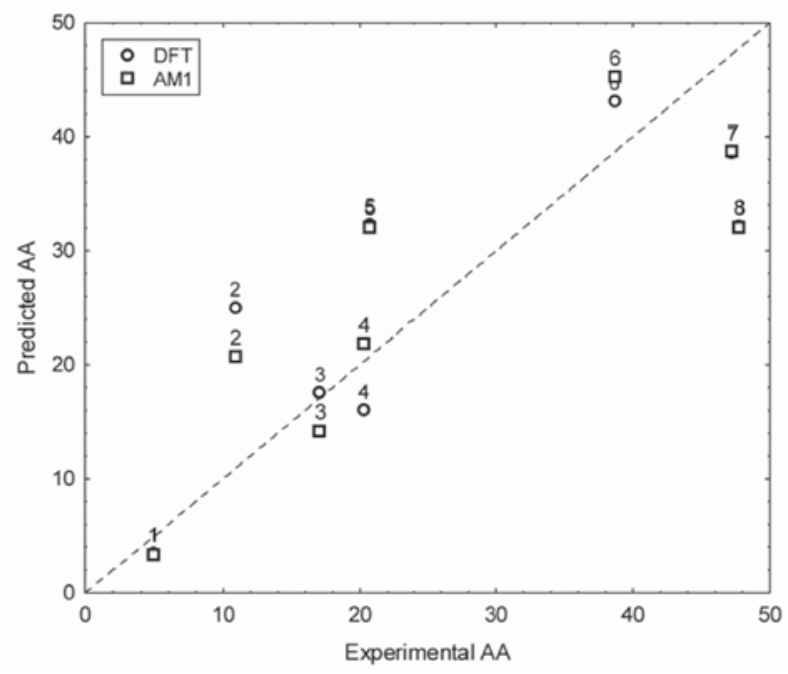

Figure 4. Plot of the B3LYP/6-31G(d,p) and AM1 predicted antiinflammatory activities against the experimental activities.

Table 3. Experimental and predicted values obtained from equations (1) and (2) for the anti-inflammatory activities of the 4-amino-2,6-diarylpyrimidine-5-carbonitriles in Figure 1

\begin{tabular}{lccc}
\hline Compound & $\mathrm{AA}_{\text {Exptl }}(\%)$ & $\mathrm{AA}_{\text {Pred, B3LYP }}(\%)$ & $\mathrm{AA}_{\text {Pred, AM1 }}(\%)$ \\
\hline $\mathbf{1}$ & 4.9 & 3.4 & 3.3 \\
$\mathbf{2}$ & 10.9 & 24.8 & 20.6 \\
$\mathbf{3}$ & 17.1 & 17.3 & 14.1 \\
$\mathbf{4}$ & 20.3 & 16.2 & 21.7 \\
$\mathbf{5}$ & 20.7 & 32.3 & 32.0 \\
$\mathbf{6}$ & 38.7 & 43.1 & 45.2 \\
$\mathbf{7}$ & 47.3 & 38.6 & 38.7 \\
$\mathbf{8}$ & 47.8 & 32.0 & 32.0 \\
\hline
\end{tabular}


plane, whereas the $\mathrm{C}_{12} \mathrm{C}_{7} \mathrm{C}_{6} \mathrm{C}_{5}$ dihedral angle is non planar. This conformation also corresponds to an AM1 minimum energy structure, which is shown in Figure 5.

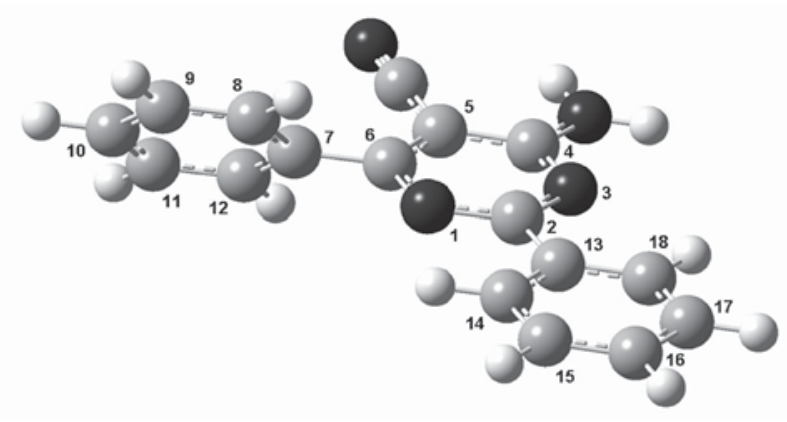

Figure 5. AM1 conformational structure for compound 6, in which the aromatic ring containing the $\mathrm{R}^{3}$ group and the pyrimidinic ring are on the same plane.

The electronic indices corresponding to this conformation were calculated for all the pyrimidinic derivatives studied. All calculations, from the correlation matrix to the principal component regression were repeated with the new AM1 results. The conclusions were the same as those reached with the fully optimized AM1 values. In particular, the regression equation is almost identical to equation 2 . This indicates that the AM1 regression model is statistically robust with respect to conformational changes.

New anti-inflammatory agents. The principal component analyses suggest that to obtain higher AA values one should try to synthesize molecules having lower $\log \mathrm{P}$, dipole moment and $\mathrm{qC}_{7}$ values, and higher $\mathrm{qC}_{13}$ values. Using these criteria, we designed two new compounds expected to be more active than those used for model building.

Introducing an electron-donor species such as a methoxy group at $\mathrm{R}^{2}$, that is, at the para position of the aromatic ring bonded to the pyrimidinic ring at position 6 , the molecular dipole moment should be reduced and the atomic charge of $\mathrm{C}_{7}$ should become more negative (or less positive), and consequently the anti-inflammatory activity of these pyrimidinic derivatives should be enhanced. Based on these considerations, we performed B3LYP/6-31G(d,p) and AM1 calculations for 4-amino2,6-diarylpyrimidine-5-carbonitriles with a methoxy or an ethoxy group at $\mathrm{R}^{2}$. The results for the new compounds, $9\left(\mathrm{R}^{2}=\right.$ methoxy $)$ and $\mathbf{1 0}\left(\mathrm{R}^{2}=\right.$ ethoxy $)$ are shown in Table 4. As expected, their dipole moments are much lower than those calculated for the compounds used to estimate the regression equations. The other variables follow the same favorable pattern, except for $\log \mathrm{P}$, which does not decrease much. Projecting these values in the $\mathrm{PC} 1 \times \mathrm{PC} 2$ planes defined by the loadings calculated with the modeling data, the scores of the new compounds can be calculated, yielding the values in the last column of Table 4. Feeding these scores into the regression equations resulted in the predicted activities shown in the same table, which indicate that compounds $\mathbf{9}$ and $\mathbf{1 0}$ should be at least as strong anti-inflammatory agents as the strongest ones used to calculate equations (1) and (2).

Following previously described experimental procedures, ${ }^{8,21,22}$ we successfully synthesized compound 9, which has a methoxy group at $\mathrm{R}^{2}$. Its anti-inflammatory activity was then evaluated following experimental procedures also described in the literature. ${ }^{9,10}$ The experimental value, $52.8 \%$, almost matches the AM1 predicted value, $52.3 \%$, and is about $5 \%$ larger than the anti-inflammatory activity of the most effective pyrimidinic derivative used in the model building phase. This lends support to predictive power of the PCR equations, despite their relatively low $\mathrm{R}^{2}$ values.

\section{Conclusion}

The molecular modeling and the statistical analyses reported in this work indicate that the anti-inflammatory activity of 4-amino-2,6-diarylpyrimidine-5-carbonitriles might be related to the molecular dipole moment and to the atomic charges of the carbon atoms through which the aromatic rings are attached to the pyrimidinic ring. Compounds with lower $\log \mathrm{P}$, dipole moment and $\mathrm{qC}_{7}$ values and higher $\mathrm{qC}_{13}$ values are expected to be more active. Two new compounds were selected based on these criteria and are predicted to be strong anti-inflammatory agents. One of them was synthesized and experimentally confirmed to be more active than any of the compounds used in the modeling step.

Table 4. Anti-inflammatory activities and B3LYP and AM1 electronic parameters for the two proposed compounds. PCA scores are given in the last column. AM1 values are given in parenthesis, and correspond to the score on $\mathrm{PC} 2^{\mathrm{a}}$

\begin{tabular}{cllllllll}
\hline Compound $^{\mathrm{b}}$ & $\mathrm{AA}_{\text {Expl }}(\%)$ & $\mathrm{AA}_{\text {Pred }}(\%)$ & $\mu(\mathrm{D})$ & $\mathrm{qC}_{7}(\mathrm{e})$ & $\mathrm{qC}_{13}(\mathrm{e})$ & $\mathrm{qC}_{16}(\mathrm{e})$ & $\operatorname{logP}$ & PCA Score \\
\hline $\mathbf{9}$ & 52.8 & $48.1(52.3)$ & $0.82(1.42)$ & $0.063(-0.113)$ & $0.042(-0.052)$ & $-0.074(-0.173)$ & 2.73 & $2.91(-2.70)$ \\
$\mathbf{1 0}$ & - & $44.6(48.4)$ & $0.86(1.23)$ & $0.062(-0.115)$ & $0.042(-0.052)$ & $-0.074(-0.173)$ & 3.22 & $2.45(-2.30)$ \\
\hline
\end{tabular}

${ }^{a} \mathrm{~B} 3 \mathrm{LYP}$ and AM1 predicted activities were calculated from equations (1) and (2), respectively; ${ }^{\mathbf{9}}$ : $\mathrm{R}^{1}=\mathrm{R}^{3}=\mathrm{H}, \mathrm{R}^{2}=\mathrm{OCH}_{3} ; \mathbf{1 0}: \mathrm{R}^{1}=\mathrm{R}^{3}=\mathrm{H}$, $\mathrm{R}^{2}=\mathrm{OC}_{2} \mathrm{H}_{5}$ 


\section{Acknowledgments}

This work is dedicated to Professor Ricardo de Carvalho Ferreira on the occasion of his $80^{\text {th }}$ birthday. Prof. Ricardo is for many reasons an inspiration for Brazilian scientists, among which we could cite his pioneering work in theoretical quantum chemistry and evolutionary biology. His example as an educator and a human being cannot be surmised from his many publications. We also gratefully acknowledge financial support from the Brazilian agencies CNPq, FINEP and CAPES.

\section{References}

1. Anderson, G. W.; Halverstadt, I. F.; Miller, W. H.; Rohlin, R. O.; J. Am. Chem. Soc. 1954, 67, 2197.

2. Heidelberger, C.; Chaudhuri, N. C.; Dannber, P.; Mooren, D.; Griesbach, L.; Duchinsky, R.; Schnitzer, R. J.; Pleven E.; Scheiner, J.; Nature 1957, 179, 663.

3. Sandanandam, Y. S.; Shetty, M. M.; Diwan, P. V.; Eur. J. Med. Chem. 1992, 27, 87.

4. Fischl, M. A.; Dickinson, G. M.; Voie, L.; J. Am. Med. Assoc. 1988, 259, 1185; Leport, C.; Raffi, R.; Metheron, S.; Katiama, C.; Regnier, B.; Simot, A. G.; Marche, C.; Vederenne, C.; Vilde, J. L.; Am. J. Med. 1988, 84, 94; Allegra, C. J.; Kovacs, A. J.; Drake, J. C.; Swan, J. C.; Chabner, B. A.; Mansur, H.; J. Clin. Invest. 1987, 79, 478.

5. Kansy, M.; Seydel, J. K.; Wiese, M.; Haller, R.; Eur. J. Med. Chem. 1992, 27, 237.

6. Gangjee, A.; Devraj, R.; McGuire Queener, S. F.; J. Med. Chem. 1997, 40, 470.

7. Melo, S. J.; Luu-Duc, C.; Thomassom, F.; Narcise, G.; Gaultier, C. ; Ann. Pharm. Fr. 1992, 50, 39.

8. de Melo, S. J.; dos Santos, L. C.; Falcão, E. P. D.; Srivastava, R. M.; Luu-Duc, C.; J. Chem. Res. (S) 2002, 5, 216.

9. Falcão, E. P. S.; PhD Thesis, Universidade Federal de Pernambuco, Recife, Brazil, 2003.
10. Falcão, E. P. S.; Melo, S. J.; Srivastava, M. R.; Jansen, M. T. A. C.; Nascimento, S. C.; Eur. J. Med. Chem. 2006, 41, 276.

11. G. Karber; B. Behrens; Statistical Methods in Biological Assay; $2^{\text {nd }}$ ed., London: Charles Griffin, 1964.

12. Frisch, M. J.; Trucks, G. W.; Schlegel, H. B.; Gill, P. M. W.; Johnson, B. G.; Robb, M. A.; Cheeseman, J. R.; Keith, T.; Petersson, G. A.; Montgomery, J. A.; Raghavachari, K.; AlLaham, M. A.; Zakrzewski, V. G.; Ortiz, J. V.; Foresman, J. B.; Cioslowski, J.; Stefanov, B. B.; Nanayakkara, A.; Challacombe, M.; Peng, C. Y.; Ayala, P. Y.; Chen, W.; Wong, M. W.; Andres, J. L.; Replogle, E. S.; Gomperts, R.; Martin, R. L.; Fox, D. J.; Binkley, J. S.; Defrees, D. J.; Baker, J.; Stewart, J. P.; HeadGordon, M.; Gonzalez, C.; Pople, J. A.; Gaussian 94, Revision E.3; Gaussian, Inc., Pittsburgh PA, 1995.

13. Dewar, M. J. S.; Zoebisch, E. G.; Healy, E. F.; J. Am. Chem. Soc. 1985, 107, 3902.

14. Hohenberg, P.; Kohn, W.; Phys. Rev. 1964, 136, B864.

15. Becke, A. D.; J. Chem. Phys. 1993, 98, 5648.

16. Frisch, M. J.; Pople, J. A.; Binkley, J. S.; J. Chem. Phys. 1984, 80, 3265.

17. STATISTICA (data analysis software system); version 6.1, StatSoft, Inc.; www.statsoft.com, 2004.

18. Program Kwwin ${ }^{\mathrm{TM}}$ v.1.67, U.S. Environmental Protection Agency, 2000.

19. Jolliffe, I. T.; Principal Component Analysis, $2^{\text {nd }}$ ed., Springer: New York, 2002.

20. Naes, T.; Isaksson, T.; Fearn, T.; Davies, T.; A User-friendly Guide to Multivariate Calibration and Classification, NIR Publications, Chichester: UK, 2002.

21. Hussain, S. M.; El-Reedy, A. M.; El-Sharabasy, S. A.; Tetrahedron 1988, 44, 241.

22. Nicicolle, E. J.; PhD Thesis, L'Université Joseph Fourier, Grenoble, France, 1990.

Received: August 22, 2007 Published on the web: February 29, 2008 